\title{
Tityus stigmurus (Thorell, 1876) (Scorpiones; Buthidae): response to chemical control and understanding of scorpionism among the population
}

\author{
Tityus stigmurus (Thorell, 1876) (Scorpiones; Buthidae): resposta ao controle \\ químico e entendimento da população sobre escorpionismo
}

\author{
Cleide Maria Ribeiro de Albuquerque ${ }^{1}$, Marcilania Oliveira Barbosa ${ }^{1}$ \\ and Luciana Iannuzzi ${ }^{1}$
}

\begin{abstract}
In this study, the events following application of the insecticide Demand 2.5 concentrated solution (CS) in the field, to control Tityus stigmurus, were investigated. Data on attitudes and practices relating to scorpionism were collected using a questionnaire. During the months of May to July 2005 , 69 premises were monitored on different days following insecticide treatment, focusing on scorpion frequency and mortality. According to the results, $42 \%$ of the premises showed scorpion incidence, with an average of three specimens per house. The highest incidence was recorded during the first week following the treatment. Only $7 \%$ of the specimens were found dead. Most (72\%) of the population showed knowledge about prevention and control measures. Despite this, $100 \%$ of the premises presented breeding sites, mainly in debris $(79.7 \%)$. These results indicate that the scorpion control method used by health agents during this investigation was not efficient, and the results suggest that the method may have had a dispersive effect on these animals.
\end{abstract}

Key-words: Community. Scorpion. Pyrethroid. Public health.

\section{RESUMO}

Neste trabalho investigou-se os eventos ocorridos após a aplicação do inseticida Demand 2,5 solução concentrada (CS) em campo para controle de Tytius stigmurus. Dados sobre atitudes e práticas relacionados ao escorpionismo foram coletados usando um questionário. Durante os meses de maio a julho/2005, 69 imóveis foram monitorados em diferentes dias após o tratamento com inseticida, focando a freqüência e mortalidade de escorpiões. Segundo os resultados, $42 \%$ dos imóveis apresentaram incidência escorpiônica com uma média de três indivíduos/casa. 0 maior índice de incidência foi registrado na primeira semana após o tratamento. Apenas $7 \%$ dos espécimes foram encontrados mortos. A maioria (72\%) da população demonstrou conhecer as medidas de prevenção e controle. Apesar disso, 100\% das residências apresentaram criadouros, principalmente entulhos (79,7\%). Esses resultados indicam que o método para controle escorpiônico usado pelos agentes de saúde, durante a pesquisa não foi eficiente, sugerindo um possível efeito dispersor sobre 0 animal.

Palavras-chaves: Comunidade. Escorpião. Piretróide. Saúde pública.

Scorpionism constitutes a public health problem in many parts of Brazil ${ }^{122}$, particularly in urban areas as a consequence of unplanned urbanization ${ }^{18}$. The effects of human activity and environmental changes have allowed expansion and colonization by opportunist species, through modifying their habitats, invading human dwellings and displacing less dangerous autochthonous species $^{12}$. The main control measure used to combat these arachnids has been the use of chemical insecticides, particularly in situations in which other alternative control measure like elimination of breeding sites, woodpiles, rocks and debris from

\footnotetext{
1. Laboratory of Terrestrial Invertebrate, Department of Zoology, Center of Biological Science, Federal University of Pernambuco, Recife, PE, Brazil

Address to: Dra. Cleide Maria Ribeiro de Albququerque. Departamento de Zoologia/UFPE.

Av. Morais Rego s/n, 50570-420 Recife, PE, Brazil.

e-mail: cleide.ufpe@gmail.com

Received in 26/10/2008

Accepted in 09/06/2009
}

areas around homes have been difficult to apply or been shown to be unsuitable ${ }^{7}$.

Amongst the various known insecticide formulations, pyrethroids are among the ones most used for pest control, both indoors and outdoors. These are synthetic derivatives of insecticidal esters called pyrethrins that are isolated from some Chrysanthemum species 5 . However, studies on the effects of these substances on scorpion survival in the field ${ }^{19}$ are still scarce. Some studies have shown that synthetic pyrethroids have an irritant effect on arthropods ${ }^{68}$, and this led Ramsey et al ${ }^{19}$ to investigate whether this effect would dislodge scorpions from their habitats, thereby provoking more contact with householders and increasing the potential to cause accidents. These authors also investigated the hypothesis that scorpions exposed to pyrethroids would present more waving of the telson, thereby contributing towards increasing the number of accidents. However, no significant increases in excitation or telson movement were found following exposure 
of Centruroides limpidus limpidus Karsch, 1879, and Vaejovis mexicans smithi Koch to lethal doses of bifenthrin, cyfluthrin and deltamethrin during fieldwork to control these species in Mexico ${ }^{19}$. Nevertheless, there has been increasing concern about the potential effects of pyrethroids on human health from long-term exposure, or from high exposure among children. Some laboratory studies have suggested that high exposure to pyrethroids might cause endocrine disruption, thereby interfering with the synthesis, secretion, binding, action or elimination of natural hormones in the body ${ }^{17}$. In addition, this may cause suppressive effects on the immune system and damage to lymph nodes and the spleen ${ }^{10} 14$

In addition to insecticide treatment, the value of community involvement and health education to improve control measures for household pest problems has been shown ${ }^{1624}$. The population can participate by removing the basic elements required for scorpion survival, such as shelter and food availability, and by blocking their access to homes by sealing cracks and crevices. Nevertheless, it is important to know whether the community is aware of its importance in the process.

In the State of Pernambuco, the records on scorpionism have been associated with Tityus stigmurus (Thorell, 1876). In natural environments, this species is found under stones, in cracks and in decomposing trees, especially in environments where the ground is very damp. However, in urban areas, Tityus stigmurus has invading human dwellings, living in roofs or among debris in backyards ${ }^{9}$. In Recife, scorpionism involving accidents with Tityus stigmurus has shown a considerable increase over recent years, including the death of one child ${ }^{15}$. Our aims in this study were to record the events that occurred as a result of spraying insecticide in the field, in order to combat Tityus stigmurus, and to study the local population's knowledge of scorpionism, in an attempt to evaluate the relative contributions of these tools as control measures against scorpions.

\section{MATERIAL AND METHODS}

Study area. This study was undertaken in Recife, a coastal city (long. $8^{\circ} 04^{\prime} 03^{\prime} \mathrm{S}$ and lat. $34^{\circ} 55^{\prime} 00^{\prime} \mathrm{W}$ ) in the state of Pernambuco. The climate is predominantly warm and wet, with a mean temperature of around $25.2^{\circ} \mathrm{C}$ and mean annual precipitation of $2,094 \mathrm{~mm}^{4}$. The data analyzed in this study come from observations made by the research group during Tityus stigmurus control actions carried out between May and July 2005, and from household interviews. The survey was conducted in Health District III, which was the district that presented the highest number of scorpion accidents in the city between 2003 and 2004 (665 reports and one fatal case $)^{2021}$. Only $30 \%$ of the neighborhoods had sanitation services. Evaluations were carried out on 69 premises whose owners had notified scorpion infestation and asked for assistance from health agents in order to control the constant presence of these animals in the house, during the six months prior to the treatment.

Data survey. The survey included two modules: 1) observation of the scorpion response to insecticide application.
2) evaluation of the householders' knowledge of scorpionism and prevention measures. The first module consisted of a control intervention with outdoor application of insecticide and evaluation of the scorpion response. The outdoor area was defined as the area surrounding the house, including debris, animal shelters and rocks (Figure 1). The premises were sprayed with a solution of the chemical insecticide Demand 2.5 concentrate. This is a microcapsule suspension formulation containing the active insecticide ingredient lambda-cyhalothrin. The product was prepared in accordance with the manufacturer's instructions (dilution $10 \mathrm{ml}$ per liter of water) and was applied by health agents, using manual-operated application equipment that delivered a coarse spray. Approximately one liter of insecticide solution was applied per $25 \mathrm{~m}^{2}$ in accordance with Syngenta ${ }^{25}$ directions. Spraying was preferentially performed outdoors around building foundations and potential breeding sites such

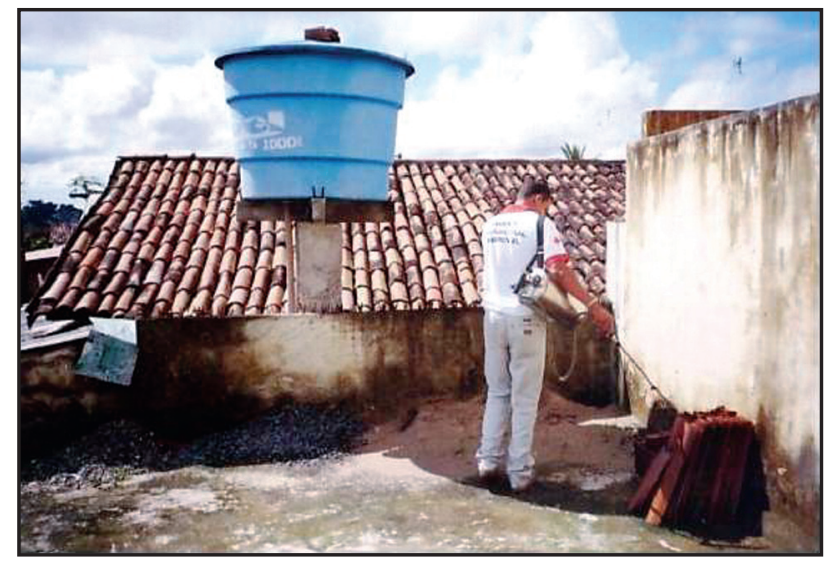

FIGURE 1

Application of chemical insecticide to control Tityus stigmurus in an urban area, Recife.

as debris and sewers. Indoor application was only carried out in premises with constant records of these animals inside the house. In the second module, the households interviewed were surveyed regarding the measures that should be adopted to avoid the presence of scorpions inside the house; the measures that should be taken when confirming the presence of or accidents with scorpions in the premises; and the knowledge that they had of the symptoms and for seeking medical care after the incident. Subsequent to applying the initial questionnaire, householders were given guidance regarding prevention, control and procedures in the event of scorpion stings. The questionnaire also sought data on building characteristics that might help to correlate scorpion presence with the house.

Post-insecticide application evaluation. The treated premises were monitored for one month following insecticide application. During this period, the premises were visited on the following days: 1, 7, 15 and 30 days after the treatment. Monitoring was conducted by interviewing householders about how often they saw scorpions in their houses: they were asked to choose between the frequencies of daily, weekly or never. If scorpions were seen, the next questions were how many specimens they had seen and what size they were. The householders kept dead scorpions to show to the researchers. After the treatment, the presence of dead 
cockroaches was investigated in order to infer the influence of food reduction on scorpion sightings.

The data were transformed into frequencies and compared using the chi-square $\left(\chi^{2}\right)$ test, with a $5 \%$ significance level.

\section{RESULTS}

Scorpion incidence. According to the answers given to the questionnaires, scorpions were found at all the sampled locations over the six-month period before applying Demand 2.5 CS. Among the interviewees, $37.7 \%$ said that they had found these arachnids inside and around their homes. Scorpions were randomly found in bathrooms, main rooms, bedrooms and kitchens (Figure 2). When asked about the sighting frequency at the time of requesting treatment, the interviewees' responses were: scorpions were seen every day $(2.9 \%)$, every week $(27.5 \%)$ and rarely (more than a one-week interval) $(69.56 \%)$.

After the treatment, the number of homes that recorded occurrences of Tityus stigmurus (29; 42\%) was significantly lower $\left(\chi^{2}=1.76 ; \mathrm{p}<0.05\right)$ than before the treatment $(69 ; 100 \%)$ (Table 1). No specimens were seen within the first twenty-four hours after the application (Table 2). Higher occurrence rates (31; 36.5\%) were recorded during the first week, averaging three specimens per home. Eighteen specimens were seen in the second week, corresponding to $21.2 \%$ of the total number of scorpions recorded. This number remained constant over the subsequent two weeks. The record of sightings of living specimens was significantly higher $\left(\chi^{2}=6.67 ; \mathrm{p}<0.05\right)$ than the record of dead ones, which corresponded to only $7 \%$ of the sample. After the treatment, these arachnids were found inside homes in the main rooms (37.9\%), bathrooms (27.6\%), kitchens (27.6\%), bedrooms (24.1\%) and other rooms (13.8\%) (Figure 2). With regard to location, the scorpion incidence in external areas increased by $12.4 \%$. Dead cockroaches and ants were recorded in all the premises.

Among the premises treated during this study, 16\% had been previously visited by health agents from Sanitary District III, who had applied insecticide. Some of the inhabitants in this area had used chemical insecticides to avoid cockroaches in their homes. From the questionnaire responses, most (75.4\%) of the interviewees had not heard of any government division responsible for controlling accidents with venomous animals. Most requests for treatment had been made during visits by environmental health agents.

Knowledge of preventive measures. When asked about the measures adopted when confirming the presence of scorpions inside homes, all of the interviewees stated they had eliminated the invader. Most of the population said that they had killed the animal using sandals (93\%). Other methods mentioned included immersing the animal in a receptacle with alcohol (4.2\%), setting it on fire after throwing alcohol on it (1.4\%) and throwing boiling water on it $(1.4 \%)$.

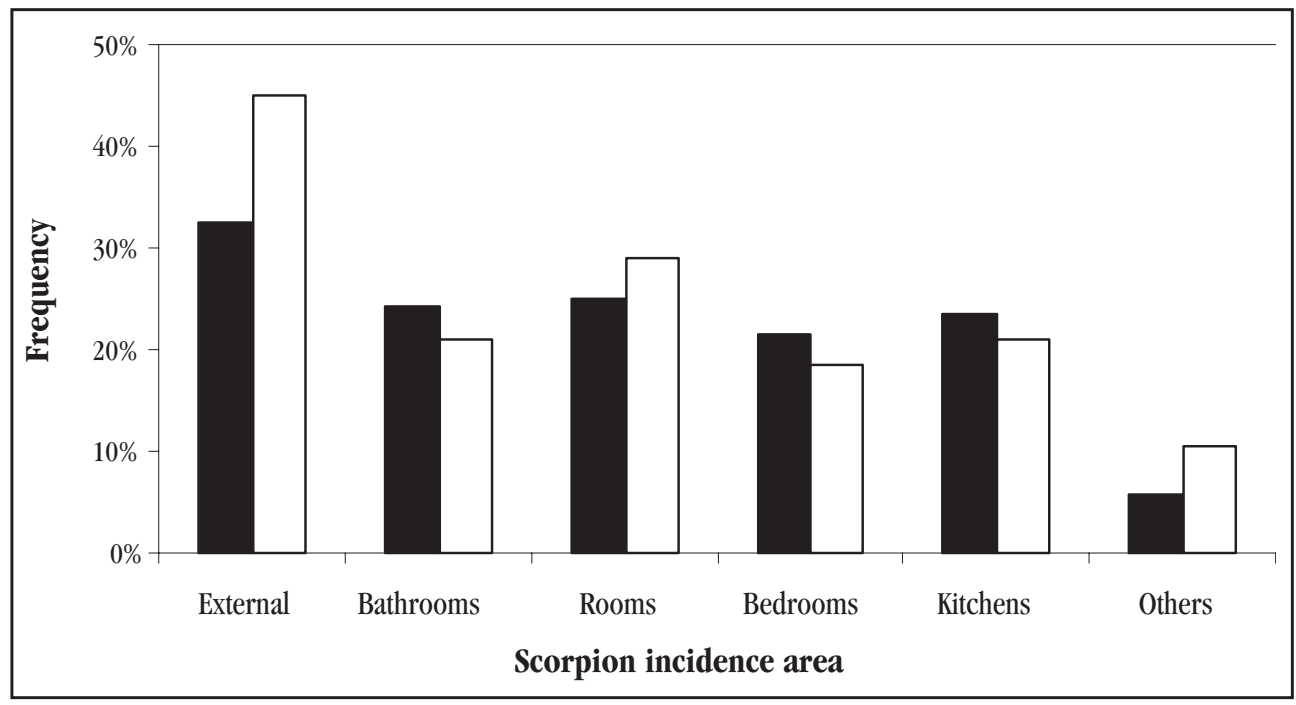

FIGURE 2

Locations in which Tityus stigmurus was found before (solid bars) and after (clear bars) treatment with chemical insecticides between May and July 2005, in Health District III, Recife.

TABLE 1

Frequency of Tityus stigmurus sightings in premises before and after treatment with chemical insecticide between May and July 2005, in nine neighborhoods of Health District III, Recife.

\begin{tabular}{lccccccccc}
\hline & $\begin{array}{c}\text { Alto José } \\
\text { do Pinho }\end{array}$ & $\begin{array}{c}\text { Casa } \\
\text { Amarela }\end{array}$ & Espinheiro & Macaxeira & Monteiro & Morro da & Nova & Passarinho & $\begin{array}{c}\text { Vasco da } \\
\text { Conceição }\end{array}$ \\
\hline Before (\%) & 100.0 & 100.0 & 100.0 & 100.0 & 100.0 & 100.0 & 100.0 & 100.0 & 100.0 \\
After (\%) & 71.4 & 100.0 & 0.0 & 42.9 & 80.0 & 100.0 & 23.5 & 25.0 & 23.0 \\
\hline
\end{tabular}




\section{TABLE 2}

Number of living and dead Tityus stigmurus specimens found indoors and outdoors at the premises investigated between May and July 2005, following treatment with chemical insecticide.

\begin{tabular}{lrrrrrr}
\hline Neighborhoods & \multicolumn{5}{c}{ Days after treatment } & \\
\cline { 2 - 5 } studied & 1 & $2-7$ & $8-15$ & $16-22$ & $23-30$ & Total \\
\hline Alto José do Pinho & 0 & $20^{*} ; 2^{* *}$ & $8^{*}$ & $10^{*}$ & $7^{*}$ & 47 \\
Casa Amarela & 0 & $1^{*}$ & 0 & $1^{*}$ & $2^{*}$ & 4 \\
Espinheiro & 0 & 0 & 0 & 0 & 0 & 0 \\
Macaxeira & 0 & 0 & $3^{*}$ & $2^{*}$ & $3^{*}$ & 8 \\
Monteiro & 0 & $4^{*}$ & $2^{*}$ & $2^{*}$ & $3^{*}$ & 11 \\
Morro da Conceição & 0 & 0 & $1^{* *}$ & 0 & 0 & 1 \\
Nova Descoberta & 0 & $1^{*}$ & $3^{*}$ & $1^{*}$ & $1^{*}$ & 6 \\
Passarinho & 0 & $1^{*}$ & 0 & 0 & 0 & 1 \\
Vasco da Gama & 0 & $2^{*}$ & $1^{*}$ & $1^{*}$ & $3^{* *}$ & 7 \\
\hline Total & 0 & 31 & 18 & & 36 & 85 \\
\hline
\end{tabular}

*number of Tityus stigmurus alive, **number of Tityus stigmurus dead.

According to the responses, $72 \%$ of the interviewees knew of at least one measure for controlling and preventing scorpions. The most common was inspecting clothes and shoes before putting them on (98\%). The notion of keeping the bouse and surroundings clean (avoiding accumulations of debris) was mentioned by $68 \%$ of the interviewees. Others was cited by $38 \%$ of the interviewees, who considered the following to be preventive measures: avoiding putting hands in holes, wearing shoes and keeping beds away from walls. Inspections were made during the monitoring phase to verify whether what was advised and suggested was being followed by the population. Most (56.5\%) of the population showed little interest in adopting preventive measures

Knowledge of first-aid measures. Among the interviewees, $23.2 \%$ stated that they had suffered from scorpionism. When asked about what measures should be taken when stung by scorpions, a significantly higher number $\left(\chi^{2}=0.12 ; \mathrm{p}<0.05\right)$ of the individuals claimed to have no knowledge of how to proceed. Out of the total number of those who had already been stung, six (35.3\%) individuals did not seek medical care after the incident and five (29.4\%) sought specialized care and took along the dead animal for identification.

Characteristics of the premises. The premises visited were of different types: residential houses, apartments, schools and commercial properties. Most (72.6\%) of the residential houses had been constructed using masonry, while $18.8 \%$ were mud huts and $8.7 \%$ were wooden huts. Among the types of potential breeding habitat in the areas surrounding the buildings that were identified during visits, waste material (rubble, debris, newspapers, plastic receptacles and sticks) were the most common ones, occurring in $79.7 \%$ of the residences. The habitats of open drainage ditches (sewage ditches and cesspits) occurred in $58 \%$, followed by piled building materials (bricks, sand and clay tiles) (52.2\%), unused land plots (47.8\%) and others (holes/openings in walls, rockeries and ornamental plants) (42\%).

\section{DISCUSSION}

One of the major problems of scorpionism is to achieve effective participation in scorpion control among the population. In the specific case of Tityus stigmurus, considering that the vast majority of breeding sites are in homes or in their vicinity, the question becomes vital in relation to the effectiveness of control measures. Although the level of knowledge of preventive measures against scorpions was high in the community studied, there was only a little evidence that this knowledge was put into practice. Observation of the areas surrounding most premises showed that the conditions were favorable for scorpion development. These animals easily adapt to the conditions offered by human homes, in which garbage and piles of bricks and tiles can become shelters, and food is abundant, in the same way that cockroaches and other insects have adapted ${ }^{22}$. All these thriving habitats were found in almost the entire sampled area. In addition, the precarious sanitary conditions and garbage collection setup in big cities have also contributed towards increasing the scorpion population and therefore, the number of scorpion accidents in Brazil $^{23}$.

Nearly one third of the individuals suffering from scorpionism do not seek medical care, thus suggesting that the number of accidents is likely to be much higher than the official records show. Supporting this hypothesis is the doubling of the number of notifications (to 1,200 cases) that was recorded in 2004 by the Health Department of Recife, following an education campaign in the media in 2003 (when there were 605 cases) ${ }^{2021}$. The state of Pernambuco presents one of the highest incidences of scorpionism in the country, with 43.5 cases $/ 100,000$.

After the insecticide application, scorpions were recorded in only $42 \%$ of the homes. This gives rise to at least two hypotheses. First, during the application, some premises were already free from scorpion infestation. It needs to be borne in mind that the survey asked about occurrences of scorpions over a six-month period. Second, a reduction in the number of infested premises would be consequent to eliminating scorpions because of the high lethality of the insecticide. However, considering that most of the specimens found in positive residences were still alive, it is unlikely that the substance used had high lethality. Studying the efficiency of three insecticides (FICAM $80 \% \mathrm{~W}$, K-Othrine 50 CS, Demand) for controlling Tityus serrulatus, Stutz et $\mathrm{al}^{23}$ demonstrated from laboratory bioassays that exposing the specimens to the insecticides tested did not significantly affect their survival. In addition, the low mortality record of Tityus stigmurus (7\%) in positive homes after applying Demand 2.5 CS under our study conditions strengthens the suggestion that the chemical insecticide used did not significantly affect the viability of this species. Although the use of chemical insecticides is one of the main control measures against scorpions, few studies have focused on the efficacy and viability of this treatment ${ }^{31819}$. According to Bücherl $^{3}$, contact insecticides diluted to $10 \%$ (the same concentration used by the health agents in the present study) only have satisfactory results when sprinkled in all areas at the same time and if the supposedly infected area is treated at least 
three times per month, for three uninterrupted months. Thus, the results shown in this study may have been influenced by how the infected area was treated, with a single application. More detailed investigations will be necessary to confirm these points.

The higher scorpion occurrence during the first week after the treatment, associated with the low mortality and absence of scorpion records in homes over the first 24 hours after the treatment, may suggest that the insecticide has a dislocating effect. Pyrethroids have irritating effects that can stimulate dispersion of scorpions ${ }^{18}$ and other arthropods ${ }^{6}{ }^{11}$. Consequent to higher scorpion activity, the chances of sightings by residents are increased, as is the risk of accidents. Some studies have correlated increased scorpion activity and accident records to the rainy season and higher temperatures, which corresponds to the reproductive period of these animals ${ }^{13}$. The treatment with Demand 2.5 CS took place between May and June, coinciding with the year's highest rainfall in this region. This may have contributed towards dispersion of animals from their hiding places due to habitat overflow. Moreover, the rain may also have reduced the effect of the insecticide, by washing it away, since it was applied mainly in the areas surrounding homes.

So far, there is no totally efficient measure for controlling scorpion populations. Chemical insecticides have shown unsatisfactory results, possibly influenced by insufficient knowledge of the biology, population dynamics and behavior of these arachnids, especially by pesticide industries. Furthermore, incorrect insecticide use, with extended and frequent exposure, may endanger people's health and cause environmental damage. Thus, better sanitary conditions and greater investments in environmental education should be encouraged as preventive measures against scorpionism. Public campaigns to make people aware of the importance of eliminating thriving habitats in areas surrounding homes and aware of the risks of scorpionism and its sequelae, which can cause temporary incapacitation from daily activities or even death, may have a better effect than chemical insecticides.

\section{ACKNOWLEDGEMENTS}

We thank the staff of the Municipal Health Department (Health District III, Recife, Pernambuco) for assisting in the fieldwork investigations.

\section{REFERENCES}

1. Barbosa MGR, Bavia ME, Silva CEP, Barbosa FG. Aspectos epidemiológicos dos acidentes escorpiônicos em Salvador, Bahia, Brasil. Ciência Animal Brasileira 4: 155-162, 2003

2. Brenner BL, Markowitz S, Rivera M, Romero H, Weeks M, Sanches E, Deych E, Garg A, Godbold J, Wolff MS, Landrigan PJ, Berkowitz G. Integrated Pest Management in an Urban Community: A Successful Partnership for Prevention. Environmental Health Perspectives 111: 1649-1653, 2003.

3. Bücherl W. Escorpiões e escorpionismo no Brasil. Memórias do Instituto Butantan 29: 243-253, 1959.

4. Campos-Filho LS. Ocorrência e comportamento alimentar do escorpião Tityus stigmurus (Scorpionidae: Buthidae), na mesorregião metropolitana do
Recife-PE. Universidade Federal de Pernambuco, Tese de mestrado em Biologia Animal. 71p, 1998.

5. Casida JE. Pyrethrum flowers and pyrethroid insecticides. Environmental Health and Perspectives 34: 189-202, 1980.

6. Chandre F, Duchon FS, Finot L, Mangiun S, Carnevale P, Guillet P. Modifications of pyrethroid effects associated with kdr mutation in Anopheles gambiae. Medical and Veterinary Entomology 14: 81-88, 2000.

7. Cupo P, Azevedo-Marques MM, Hering SE. Escorpionismo. In: Cardoso JLC, França FOS, Wen FH, Málaque CMS, Haddad Jr V (eds) Animais peçonhentos do Brasil: biologia, clínica e terapêutica dos acidentes. Savier/Fundação de Amparo à Pesquisa do Estado de São Paulo, p.198-207, 2003.

8. Desneux N, Decourtye A, Delpuech J-M. The Sublethal Effects of Pesticides on Beneficial Arthropods. Annual Review of Entomology 52: 81-106, 2007.

9. Eickstedt VRD. Escorpionismo por Tityus stigmurus no nordeste do Brasil (Scorpiones; Buthidae). Memórias do Instituto Butantan 47/48:133-137, 1983/1984.

10. Go V, Garey J, Wolff MS, Pogo BGT. Estrogenic potential of certain pyrethroid compounds in the MCF-7 human breast carcinoma cell line. Environmental Health and Perspectives 107: 173-177, 1999.

11. Gurtler RE, Schweigmann NJ, Cecere MC, Chuit R, Wisnivesky-Colli C. Comparison of two sampling methods for domestic populations of Triatoma infestans in north-west Argentina. Memórias do Instituto Butantan 7: 238-242, 1993.

12. Lourenço WR, Cuellar 0. Scorpions, scorpionism, life history strategies and parthenogenesis. Journal of Venomous Animals and Toxins 1: 51-62, 1995.

13. Lucas $S$. Principais aranhas e escorpiões de interesse médico. Reconhecimento. Distribuição geográfica. In: Soerensen B (ed) Acidentes por animais peçonhentos: reconhecimento, clínica e tratamento. Atheneu, São Paulo, p.65-73, 1996.

14. Madsen C, Claessen MH, Ropke C. Immunotoxicity of the pyrethroid insecticides deltametrin and $\alpha$-cypermetrin. Toxocology 107: 219-227, 1996.

15. Ministério da Saúde. Sistema de Informação de Agravos de Notificação. Secretaria de Vigilância em Saúde. Tabulação de dados - TabNet. Disponível em http:// dtr2004.saude.gov.br/sinanweb/index.php?name=Tnet. Acessado durante 0 ano de 2006, para informações de 2001 a 2005.

16. Ministério da Saúde. Sistema Nacional de Vigilância em Saúde: relatório de situação: Pernambuco. Secretaria de Vigilância em Saúde. Projetos, Programas e relatórios $3^{\text {a }}$ edição, Brasília, Ministério da Saúde, 2007.

17. Moniz AC, Cruz-Casallas PE, Salzgeber AS, Varoli FMF, Spinosa HS, Bernardi MM. Behavioral and endocrine changes induced by perinatal fenvalerate exposure in female rats. Neurotoxicology and Teratology 27: 609-614, 2005.

18. Nunes CS, Bevilacqua PD, Jardim CCG. Aspectos demográficos e espaciais dos acidentes escorpiônicos no Distrito Sanitário Noroeste, Município de Belo Horizonte, Minas Gerais, 1993 a 1996. Cadernos de Saúde Pública 16: 213-223, 2000.

19. Ramsey JM, Salgado L, Cruz-Celis A, Lopez R, Alvear AL, Espinosa L. Domestic scorpion control with pyrethroid insecticides in Mexico. Memórias do Instituto Butantan 16: 356-363, 2002

20. Secretaria Municipal de Saúde. Relatório sobre Número de Acidentes Escorpiônicos no município de Recife em 2003. Recife: Diretoria Epidemiológica e Vigilância a Saúde, Prefeitura do Recife, 2005a.

21. Secretaria Municipal de Saúde. Relatório sobre Número de Acidentes Escorpiônicos no município de Recife em 2004. Recife: Diretoria Epidemiológica e Vigilância a Saúde, Prefeitura do Recife, 2005b.

22. Soares MRM, Azevedo CS, De Maria M. Escorpionismo em Belo Horizonte, MG: um estudo retrospectivo. Revista da Sociedade Brasileira de Medicina Tropical 35:359-363, 2002

23. Stutz WH, Bendeck 0, Macedo EM, Camargo JCC, Oliveira FS, Bonito RF. Bioensaio Visando Controle de Escorpionídeos (Tityus serrulatus), através do uso de Bendiocarb, Deltamethrin e Lambda-cyhalothrin, 2003. Disponível em: http:// www.geocities.com/HotSprings/5967/bioensaio.html. Acesso em 30 junho 2008.

24. Toledo ME, Vanlerberghe V, Baly A, Ceballos E, Valdes L, Searret M, Boelaert M, Van der Stuyf P. Transactions of the Royal Society of Tropical Medicine and Hygiene 101: 56-63, 2007.

25. Syngenta. Disponível em <http://www.syngenta.com.br/pt/produtos/demand. asp $>$. Acesso em 03 junho 2005. 